\title{
Dijital Bankacılıkta Müşteri Memnuniyetinin Çok Kriterli Karar Verme Yöntemleri ile Değerlendirilmesi ${ }^{1}$
}

\author{
Elçin NOYAN² ve Erdoğan GAVCAR ${ }^{3}$
}

\section{$\ddot{O} z$}

Bilgi paylaşımının, akıllı telefonların kullanımı ile arttı̆̆ı, dijjitlleşme sürecinin hızlandığı günümüzde bankalar, müşterilerinin ihtiyaçlarını hızlı bir şekilde karşılamak için adeta yarış haline girmişlerdir. İçinde bulunduğumuz Koronavirüs (Covid 19) Salgını ile Dijital Bankacıllğa yönelim artmış, Dijital Bankacıllk gerek sağlık tedbirleri, gerekse bankaların işlem maliyetlerinin düşürülmesi, işlemler için belge, doküman gerektirmemesi yönleriyle, bankacılık hizmet kalitesinin artırlması ve müşteri memnuniyetinin sağlanması açısından önemli hale gelmiştir. Bu bağlamda literatürde Dijital Bankacıllk ile ilgili çalışmalar genellikle sadece internet bankacılığı ürünüyle sınırlı kalmıştır. Çalışmanın amacı Dijital Bankacılık ürünlerini kullanımında müşterilerin memnuniyetlerine etki eden faktörlerin belirlenmesidir. Çalışmada, Muğla ili ve çevresine yüz yüze anket yoluyla elde edilen 170 adet veri Çok Kriterli Karar Verme (ÇKKV) Yöntemleri'nden Analitik Hiyerarşi Prosesi Yöntemi (AHP) temelli Multi-Objective Optimization on Basis of Ratio Analysis (MOORA) ve Elimination and Choice Translating Reality (ELECTRE)Yöntemleri kullanılarak analizler yapılmıştır. Analizler, Microsoft Excel programı ile gerçekleştirilmiş, elde edilen sonuçlar birbirleri ile kıyaslanmıştır. Çalışma sonucunda müşteri memnuniyetine en çok etki eden kriterin "güven" olduğu görülmüştür. Dolayısıyla bankalar müşterilerini Dijital Bankacılık kanallarına yönlendirirken bu kanalların güvenli olduklarını vurgulamalı, kurum olarak ta bankalar müşterilerine güven vermelidirler. Elde edilen sonuçlar literatüre de paralellik göstermiştir. Dijital Bankacilık ürünlerinin kullanımının önündeki engellerin aşılması konusunda çalışmalar artırlmalı, toplumun dijitalleşmeye karşı güvensizlik algısı giderilmelidir.

Anabtar Kelimeler: Dijital bankacıllk, Müşteri memnuniyeti, Çok kriterli karar verme, ELECTRE, MOORA

\section{Evaluation of Customer Satisfaction in Digital Banking with Multi Criteria Decision} Making Methods

\begin{abstract}
In today's world, where information sharing increases with the use of smart phones and the digitalization process accelerates, banks have entered the race to meet the needs of their customers quickly. With the Coronavirus (Covid 19) Epidemic we are in, the trend towards digital banking has increased, and digital banking has become important in terms of reducing the transaction costs of banks, increasing the quality of banking services and ensuring customer satisfaction in terms of not requiring documents and documents for transactions. In this context, studies related to Digital Banking in the literature are generally limited only to the Internet banking product. The purpose of the study is to determine the factors that affect the satisfaction of customers in the use of Digital Banking products. In the study, 170 data obtained through face-to-face questionnaire in and around Muğla province were based on Analytical Hierarchy Process (AHP), MultiObjective Optimization on Basis of Ratio Analysis (MOORA) and Elimination and Choice Translating Analyzes were made using Elimination and Choice Translating Reality (ELECTRE) Methods. Analysis made with Microsoft Excel Program and results were compared with each other. As a result of the study, it is seen that the criterion that has the most impact on customer satisfaction is 'trust'. Therefore, while banks direct their customers to the Digital Banking channels, they should emphasize that these channels are safe and banks should trust their customers as an institution. The results obtained were parallel to the literature. Efforts to overcome obstacles to the use of Digital Banking products should be increased, and the public's sense of insecurity towards digitalization should be eliminated.
\end{abstract}

Key Words: Digital banking, Customer satisfaction, Multi criteria decision making, ELECTRE, MOORA

\section{Atıf İçin / Please Cite As:}

Noyan, E. ve Gavcar, E. (2020). Dijital bankacılıkta müşteri memnuniyetinin çok kriterli karar verme yöntemleri ile değerlendirilmesi. Manas Sosyal Araştırmalar Dergisi, 9(4), 2349-2363.

Geliş Tarihi / Received Date: 29.04.2020

Kabul Tarihi / Accepted Date: 08.09.2020

\footnotetext{
${ }^{1}$ Çalışma 'Dijital Bankacılıkta Müşteri Memnuniyetinin Çok Kriterli Karar Verme Yöntemleri ile Değerlendirilmesi' adlı doktora tezinden türetilmiştir.

${ }^{2}$ Doktora Öğrencisi. - Muğla Sttkı Koçman Üniversitesi, Sosyal Bilimler Enstitüsü, elcinnoyan@hotmail.com ORCID: 0000-0003-2630-0274

3 Prof. Dr. - Muğla Sttkı Koçman Üniversitesi İktisadi ve İdari Bilimler Fakültesi, gavcar@mu.edu.tr ORCID: 0000-0002-2748-3933
} 


\section{Giriş}

Dijitalleşme, toplumda elektronik sistemlerin gelişmiş teknoloji kullanılarak bilgiye daha az çaba ile ulaşabilmektir (Adiloğlu ve Yücel 2018, s. 47). Dijital bankacıllk ise, her türlü bankacıllı hizmetlerinin banka şubelerine gidilmeksizin bilgisayarlar, telefonlar veya televizyonlar aracilğıyla müşterilere ulaştırılabilmesidir. Böylelikle, zamandan tasarruf sağlanmakta, belge ve doküman gönderme ișlemlerine ihtiyaç duyulmamaktadır (Daniel, 1999, s. 72). Türkiye'de ilk dijital banka, 2012'de “enpara.com” ile Finansbank olmuştur. ATM kullanımı ise 1987 yılında İş Bankası tarafından, satış noktası terminalleri (POS) ise 1989 yllından itibaren kullanılmıştır. 1990 yllı sonunda Türkiye'de plastik kartlar ve otomatik vezne makinelerinin (ATM) kullanımı artmıştır (Takan, 2002, s. 3). Türkiye'de Yapı Kredi Bankasının ofis bankacılık uygulaması TeleROM, Tele Firma adı ile hizmet vermeye, Akbank, Aklink ve AkPC ile İş Bankası İnteraktif PC ile ofis bankacilığı sistemleri kullanılmaya başlanmıştır (Özcan, 2007, s. 2). Günümüzde giderek geliştirilen dijjital bankacılık ürünleri, akıllı telefonlar aracıllğıyla göz tarama teknolojisi güvenli giriş işlemleri, QR kod para çekme, yapay zekâ ile chatbot'lar ve ses tanıma teknolojileri, bankaların ürünlerini yeniden tasarımlarını sağlamaktadır (https://www.garantibbvamortgage.com).

Tablo 1. 2018 ve 2019 Yillar Bankacilk Verileri

\begin{tabular}{lcc}
\hline & 2018 & 2019 \\
\hline Şube Sayıs1 & 10.454 & 10.199 \\
Banka Kartı Sayıs & 146.375 .337 & 166.211 .057 \\
Kredi Kartı Sayıs1 & 66.304 .603 & 69.825 .826 \\
ATM Sayıs1 & 51.941 & 53.024 \\
Personel Sayıs1 & 192.313 & 188.837 \\
& &
\end{tabular}

Tablo 1 incelendiğinde, 2018 yllı verilerine göre 2019 yllında şube ve personel sayılarında azalış,banka, kredi kartları ve ATM sayılarında ise artış görülmektedir. Bankalarda dijitalleşmenin banka çalışanları ve şube sayılarında azaltıcı etkisi olduğu görülmektedir (tbb.org.tr).

Dijital Bankacılık dağıtım kanalları: kurumsal dağıtım kanalları: otomatik takas sistemleri, elektronik nakit yönetimi, elektronik fon transferi (EFT), uluslararası para transferi (SWIFT), satış noktasında elektronik para transferi (EFTPOS); bireysel dağıtım kanalları ise otomatik vezne makineleri(ATM), plastik kartlar, elektronik para, internet bankacillğı, telefon bankacıllğı, mobil bankacılık, SMS tabanlı uygulamalar, ev ve ofis bankacilğ̆1, televizyon bankacillğı, Palm (avuç içi) uygulamaları, kabin bankacilı̆̆1 (KIOSK)'dır (Bakkal ve Aksüt, 2011, s. 25-49). Türkiye'de 2019 yll sonu itibariyle toplam aktif bireysel dijital müşteri sayıs1 51.014, kurumsal dijital müşteri sayıs1 2.143, toplamda ise 53.157 (bin kişi)'dir (https://www.tbb.org.tr).

\section{Bankacılıkta Müşteri Memnuniyeti}

Memnuniyet, kişinin bir üründen beklentileri ile üründen elde edilen performans arasındaki ilişkinin kıyaslanmasıdır (Saha ve Zhao, 2005, s. 42; Rust ve Oliver, 1994, s. 4). Müşteri memnuniyeti bankalar açısından önemlidir çünkü uzun vadede mevcut müşterileri elde tutmanın maliyeti yeni müşteriye sahip olmaktan daha düşüktür (Mishra, 2009, s. 46). Bankacillkta müşteri memnuniyetini etkileyen faktörler: beklentiler, ürün kalitesi, performans, güvenilirlik, uygunluk, hizmet kalitesi, ün/ alg1lanan kalite, kullanım kolaylığı, düşük maliyet ve işlem hızıdır (Bilir, 2010, s. 39).

\section{Bankac1lıkta Hizmet Kalitesi}

Literatürde en çok başvurulan yöntemler: Grönroos (1984)'un hizmet kalitesi modeli ile Parasuraman, Zeithaml ve Berry (1988)'nin algilanan hizmet kalitesi boşluk analizi modelidir. Hizmet kalitesi modelleri. İskandinav Modeli, Amerikan (SERVQUAL) Modeli ve SERVPERF Modeli'dir.

\section{İskandinav Modeli}

1980 y1lında ortaya atılan İskandinav modelinde hizmet kalitesi "İşlevsel Kalite" ve "Teknik Kalite" olarak iki ayrı boyuta ayrilmaktadır (Gronroos, 1984, s. 36-37, Parasuraman vd.1988, s. 12-40). 


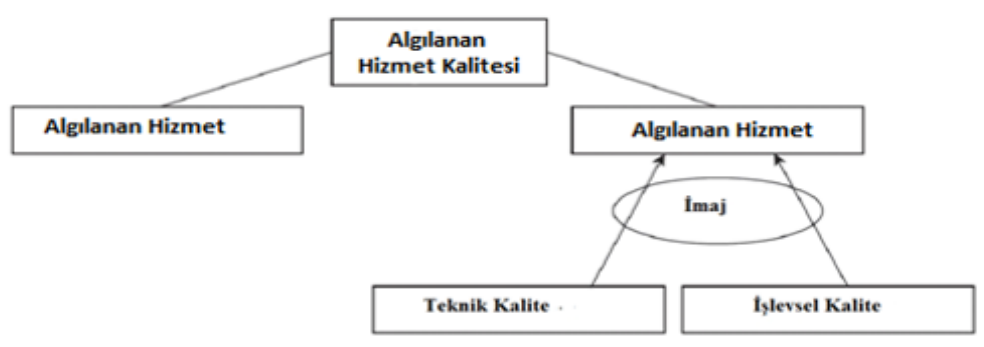

Şekil 1. Iskandinav Modeli

Şekil 2'deki İskandinav modeli (Polyakova ve Mirza, 2015, s. 59-82) alt boyutlarından teknik kalite, tüketicilerin bir hizmet organizasyonu ile etkileşim sonucu elde ettiği bir unsur olup, işlevsel kalite tüketicilerin hizmet alma şekli ile ilgilidir (Gronroos, 1984, s. 36-44). Gronroos'un teknik ve işlevsel kalite modeli, şirketlerin rekabetçi kalmak ve büyümek amacıyla hizmet kalitesi ile ilgili müşterilerin algılarını temel almıştır (Kumarapperuma, 2014, s. 43).

\section{Amerikan (SERVQUAL) Modeli}

Amerikan modeline veya SERVQUAL modeline göre, hizmet kalitesi, beklenen hizmet düzeyi ve alınan düzeydeki müşteri algıları arasındaki farktır. Şekil 3'de paylaşıldığ gibi bu fark algılanan hizmet kalitesini oluşturur. Parasuraman, Zeithaml ve Berry on bileşenli hizmet kalitesi önerilmiştir, bunlar; "güvenilirlik, heveslilik, yeterlilik, erişilirlik, nezaket, iletişim, inanılırlık, emniyet, müşteriyi anlama/tanıma ve fiziki görünüm” dür (Polyakova ve Mirza, 2015, s. 66).

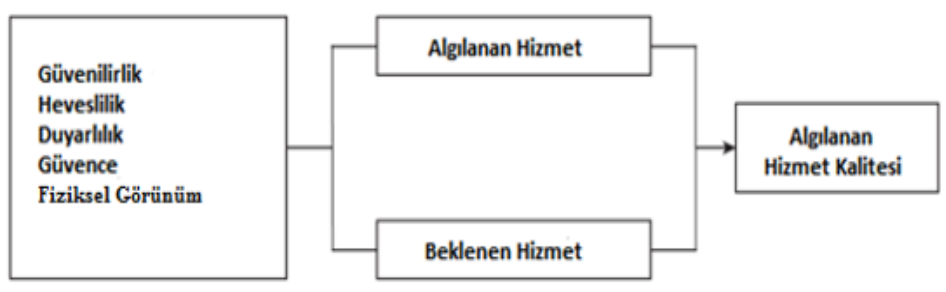

Şekil 2. SERVQUAL Modeli

Parasuraman, Zeithaml ve Berry'e göre hizmet kalitesi, müşteri beklentileri ile müşteri algı puanlarının farkıdır (Parasuraman vd., 1985, s. 41-50). Olumlu puanın yüksek olması ile hizmet kalitesi yükselmekte veya tam tersi durumda da azalmaktadır.

\section{SERVPERF Modeli}

İskandinav modeline yapılan eleștiriler SERVPERF modelinin ortaya çıkmasına yol açmıștır (Roland ve Oliver, 1994, s.10-12). Hizmet kalitesinin performansa dayalı bir modeldir (Cronin ve Taylor, 1992, s. 56).

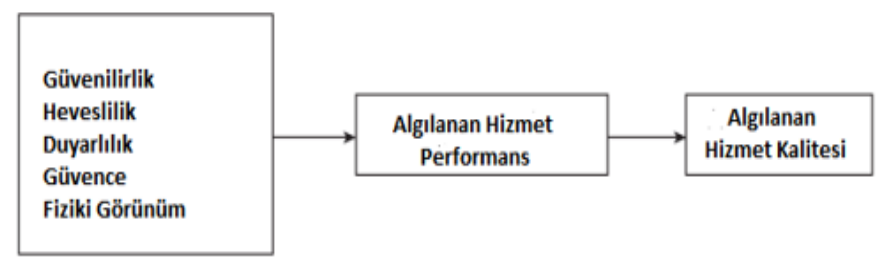

Şekil 3. SERVPERF Modeli

\section{Literatür}

Rod vd. (2009) Kıbrıs bankalarında en önemli hizmet kalitesi boyutunun güven, en az öneme sahip boyutun ise fiziksel özellikler olduğu belirlenmiştir. 
Araslı vd. (2009) banka müşterilerinin beklentilerinin genellikle karşılanmadığını, empati boyutunda büyük farklılıklar bulunduğu ve güven boyutunun müssteri memnuniyetinde önemli etkiye sahip olduğu ifade edilmiştir.

Usta (2009) yaptı̆̆1 çalışmada güvenilirlik, güven, empati ve fiziksel özelliklerden oluşan hizmet kalitesi boyutlarının önem dereceleri Analitik Hiyerarşi Süreci (AHS) yöntemi ile belirlenmiş, güvenilirliğin ise hizmet kalitesi boyutlarından en önemli boyut olduğu ortaya konulmuş,

Pala ve Kartal (2010) internet bankacıllı̆ına yönelik müşteri tutumları incelendiğinde; zaman, kolaylik ve güvenlik kriterleri öne çımış, müşterilerin şubesiz bankacılık hizmetlerini kullanmalarını etkileyen faktörlerin, güvenirlik ve yeterlilik kriterleri bakımından doğru yönlü ilişki olduğu ortaya koyulmuştur.

Amiri ve Faghani (2012) İran'daki bankaların mobil bankacilık hizmetlerinin kalitesi SERVQUAL modeli ile incelenmiş, mobil bankacllık hizmetleri ile müşteri memnuniyeti arasında anlamlı ilişki bulunmuştur.

Nimako vd. (2013) Gana'da bankacıllk sektöründe internet şubesinde hizmet kalitesi, müşteri memnuniyeti değerlendirilmiş, banka müşterilerinin müşteri hizmetleri ve web tasarımından memnun olmadıkları, güvence boyutu için müşteri memnuniyetinin yüksek olduğu tespit edilmiştir.

Orçanlı ve Özdemir, (2013) kredi kartı seçiminde Analitik Hiyerarşi Prosesi Yöntemi (AHP) ile ELECTRE yöntemleri birlikte kullanılmış, bankanın hizmet kalitesi, taksitlendirme imkânları, sağlanan ek avantajlar, ödeme koşulları, internet bankacilığı hizmetleri, kartların kullanım kolaylığı, hizmete kolay ulaşabilme, bankanın karta uyguladığı güvenlik hizmetlerinden memnuniyet kriterleri incelenmiştir.

Sagib ve Zapan (2014) Bangladeş’te mobil bankacılık hizmet kalitesini ölçmeye yönelik çalışmalarında, mobil bankacilıkla ilgili olarak güvenilirlik, güvenlik, sorumluluk, verimlilik, uygunluk ve kullanım kolaylı̆g kriterlerinin etkileri ve müşteri memnuniyeti ile mobil bankacllık hizmet kalitesinin kuvvetli bir faktör olduğu sonuçlarına varılmıştır.

Uygurtürk (2015) bankaların internet şubeleri Bulanık MOORA Yöntemi ile değerlendirilmiş, teknik problem sıklığı, cevap verme süresi, kullanım kolaylığı, kişiselleştirme imkânı, güvenlik seviyesi, çevrimiçi bağlantı kolaylığı, yönlendirme kolaylığı, bilgi kriterleri temel alınmıştır.

Ortstad ve Sonono (2017) Dijital dönüşüm sürecinin bankaların müşteri ilişkileri üzerindeki etkileri incelenmiş, toplumdaki dijital ilerlemeler nedeniyle, bankalar kendilerini dijital olarak dönüştürmek için dijitalleşme süreçlerine başlamasında müşterileri ile olan ilişkisini etkilediği görülmüsstür. Dijital stratejinin iş stratejisi ve CRM ile uyumlaştırılması, bankaların müşteri davranışındaki değişiklikleri daha hızlı fark ettiği sonuçlarına varılmıştır.

Demirel (2017) Dijital Bankacıllk ve Türkiye'deki mevcut durum analiz edilmiş, internet bankacillğı ve mobil bankacılık kullanımları değerlendirilmiş, internet bankacıllı̆ının daha yaygın olarak kullanıldığı görülmüştür.

Bülbül (2017) Türk bankacılık sektöründe katılım bankaları ve mevduat bankaları açısından karşılaştırılmıştır. Hizmet çeşitliliği, faizle daha fazla kazanç sağlama olanaklarından ve mevduat bankalarının, katılım bankalarına göre müşteri memnuniyeti açısından daha ileride olduğu vurgulanmıştır.

Gürbüz (2019) hizmet kalitesinin ölçülmüş, algilanan hizmet kalitesinin yatırımcı memnuniyeti ve sadakatini etkileyip etkilemediği araştırılmış, müşteriler arasında hizmet kalitesini belirleyen en büyük etken finans kuruluşunun güvenilirliği olmuştur. Bu nedenle yatırım kurumlarının verdiği hizmette, maliyet, işlem hızı, karlılık oranı gibi avantajları ile birlikte güvenilir olma statülerini güçlendirmeleri gerektiğini ortaya koyulmuştur.

Ertuğrul ve Sarı (2019) hizmet kalitesi ölçümünde Servqual Tekniği bir üniversite üzerine uygulanmıs, güvenilirlik boyutundaki beklenti ve alg1 farkının yüksek olduğu, fakültedeki öğrencilerin memnuniyetlerini artırmaya yönelik stratejiler geliştirilmesi gerektiği ortaya koyulmuştur.

\section{Yöntem}

Bu bölümde Çok Kriterli Karar Verme (ÇKKV) Yöntemleri'nden Analitik Hiyerarşi Prosesi (AHP) temelli MOORA ve ELECTRE yöntemleri kullanılarak Dijital Bankacilık ürünlerini kullanan banka müşterilerinin memnuniyetleri ölçülmüştür. Kriterlerin ağırlıklarının objektif olması açısından AHP yöntemi ile yapılmıştır. 


\section{Çok Kriterli Karar Verme Yöntemleri}

İșletmelerin karar verme süreçlerinde birden fazla kriteri göz önünde bulundurmaları, bu kriterler doğrultusunda eş zamanlı olarak ele almalarını sağlayan yöntemdir (Tütek, Gümüşoğlu ve Özdemir, 2012, s. 331-332). ÇKKV, bir karar kümesi için karar vericiye en iyi kararı verme, karar vericinin bir küme için en az iki kriter/ölçüt ile yaptığı seçimdir. Bu seçim gruplandırma ya da sıralama şeklinde de olabilir (Organ ve Kenger, 2012, s. 5). ÇKKV Yöntemleri sıralanırsa (Karakaşoğlu, 2008, s. 19-28 ): Analitik Hiyerarşi Süreci (AHP), Entropi, Gri İlişkisel Analiz (GRA), Multi Attribute Utility Theory (MAUT), Additive Ratio Assesment (ARAS), Multi-Objective Optimization on Basis Of Ratio Analysis (MOORA), Elimination and Choice Translating Reality (ELECTRE), Technique for Order Preference by Similarity to Ideal Solution (TOPSIS), Preference Ranking Organization Method for Encrichment Evaluations (PROMETHEE), Vise Kriterijumska Optimizacija I Kompromisno Resenje (VIKOR), Complex Proportional Assesment (COPRAS), Utilities Additives Discriminantes (UTADIS).

\section{Analitik Hiyerarşi Prosesi (AHP)}

1977 yllinda Thomas L. Saaty tarafindan karmaşık problemlerin çözümü için ortaya koyulmuş, farklı kriterlerin alternatifler arasından en iyisini seçmek üzere geliştirilen yöntemdir (Saaty, 1986, s. 841, Zahedi, 1986, s. 16-26). Kriterler ve alternatiflerin ikili karşılaştırılmasına dayanmakta, birden fazla hiyerarşik yapıdan oluşmaktadır (Saaty, 1990, s. 22). Yöntemin amac1, hiyerarşik yapıda yer alan her bir kriterin önem derecelerini ve ağırlıklarını belirlemektir (Saaty, 1977, s. 234-281). İlk aşamada, problemde ana kriterler varsa alt kriterler tespit edilip ikili karşılaştırmaların doğru şekilde yapılması gerekmektedir (Braunschweig ve Becker, 2004, s. 9). İkinci aşamada ikili karşılaştırmalar matrisi, bir kriterin diğerine göre ne kadar önemli olduğunu gösteren 1-9 önem skalası kullanılmaktadır (Saaty, 1990, s. 22). İkili karş̧1laştırma matrisi elde edilip bu matristen yeni bir B matrisi oluşturulur. Oluşturulan B matrisinden karar kriterlerinin ağırlık vektörleri elde edilir. Her bir sütunun toplanması ve matristeki diğer elemanlara bölünmesi ile normalizasyon işlemi yapılmaktadır. Her bir alternatif kriterin satır ortalaması, kriterlerin öncelik değerleri hesaplanır. Öncelik değerleri ile öncelik vektör matrisi elde edilir. Her bir kriter öncelik değerleri ile çarpılması ile ağırlıklandırılmış toplam matris elde edilir. Ağırlıklandırılmış olan toplam matrisin satır toplamı değerleri, öncelik matrisi satır değerlerine bölünür ve (nx1) boyutundaki son matris değerlerinin aritmetik ortalaması $\lambda$ max değerini verir (Özyörük ve Özcan, 2005). İkili karşılaştırmaların belirlenen değerin sınırları içinde olması tutarlılık analizi için önemlidir. $C I=\lambda \max -n /(n-1)$. Elde edilen değerin rassallık indeksine bölünmesi ile tutarlılık oranı hesaplanır. Bu oran 0.10 değerine eşit veya bu değerden küçük ise analiz tutarlıdır. Aksi halde analizler tekrar yapılmalıdır (Göktolga ve Gökalp, 2012, s. 75-76).

\section{MOORA (Multi-Objective Optimization on Basis of Ratio Analysis) Yöntemi}

2006 yılında ilk kez Brauers ve Zavadskas tarafından ortaya atılan belirli kısıtlar ile eş zamanlı olarak en iyiyi seçme süreci, oransal analize bir karar verme yöntemidir. MOORA yöntemi, diğer ÇKKV yöntemlerden hesaplanması basit olması, daha az matematiksel işlem gerektirmesi ve güvenilir olması açısından tercih edilmektedir (Brauers ve Zavadskas, 2012, s. 1-25). Yöntemin, MOORA-Oran Metodu, MOORA-Referans Noktası Yaklaşımı, MOORA-Önem Katsayısı, MOORA-Tam Çarpım Formu ve MULTI-MOORA modelleri bulunmaktadır (Ersöz ve Atav, 2011, s. 78-87).

\section{MOORA-Oran Yöntemi Adımları:}

1.Adım : Amaçlar belirlenir.

2. Adım : Matris normalize edilir.

3. Adım : Normalize edilen maksimizasyon performans değerleri toplamının, minimizasyon performans değerleri toplamı farkının alınması ile değerler eşitlik 1 yardımıyla büyükten küçüğe doğru sıralanır.

$$
\mathrm{x}^{*} i j=\frac{\mathrm{x}_{\mathrm{ij}}}{\sqrt{\sum_{i=1}^{m} \mathrm{x}^{2} \mathrm{ij}}}
$$

$i=1,2, \ldots, m$ alternatif sayısını, $j=1,2, \ldots, n$ kriter sayısını göstermektedir. $x^{*} i j$, i. alternatifin $j$. kriter için değerlerin normalleştirmesi ile elde edilir (Önay ve Çetin, 2012). $x^{*} i j \in[0,1]$ aralı̆̆ındadır.

$$
\mathrm{y}^{*} i=\sum_{j=1}^{\mathrm{g}} \mathrm{x}^{*}{ }_{\mathrm{ij}}-\sum_{j=g+1}^{\mathrm{n}} \mathrm{x}^{*}{ }_{\mathrm{ij}}
$$


Eşitlik 2' de, $i$ : alternatif, $j$ : nitelik ya da ölçüt, $g$, maksimize edilecek, (n-g) minimize edilecek kriter sayısını, $n$ : toplam nitelik ya da ölçüt sayısı, $x i j: i$. alternatifin $j$. ölçüt açısından performans ölçüm değeri olarak ifade edilir. xij değeri $j$. ölçüt ya da nitelik açısından $i$. alternatifin normalize edilmiş değeridir.

\section{MOORA-Referans Noktası Yaklaşımı}

Normalize edilen değerler, seçeneklerin her bir amaca göre maksimizasyonda en iyi değeri, minimizasyon da ise en düşük değeri referans noktası (ri) 'dir. Eşitlik 3 ile kriterlerin referans noktasına uzaklıkları hesaplanır (Brauers ve Zavadskas, 2009, 24).

$$
d i j=|r i-x i j *|
$$

"Eşitlik 4 ile her seçeneğin en yüksek değeri hesaplanır, seçenekler küçükten büyüğe doğru sıralanır. Birinci sırada yer alan alternatif en iyi seçenektir (Stanujkic vd., 2012, s. 141-154).

$$
P i=\min i(\max j d i j)
$$

Alternatiflerin performans değerleri eşitlik 5 ile elde edilir (Brauers ve Zavadskas, 2012, s. 1-25).

$$
\begin{aligned}
& y i *=\sum w j x i j *-\sum w j x i j * \\
& d i j=w j|r i-x i j *|
\end{aligned}
$$

Böylece $y i *$, değerleri büyükten küçüğe doğru sıralanır, $y i *$ sıralamasına göre ilk sıradaki seçenek en uygun seçenek olarak kabul edilir.

\section{ELECTRE (ELimination Et Choix Traduisant la REalité) Yöntemi}

Benayoun tarafindan 1966 yllinda ortaya atılan yöntem ile alternatiflerin tercih edilme sırasına göre kıyaslanıp seçim yapılması temeline dayanmaktadır (Kuru, 2011, s. 129-144). ELECTRE Yöntemleri, karşılaşılan somut ve spesifik bir problemi çözmeyi amaç edinir (Roy and Vanderpooten, 1996, s. 23). Günümüze kadar, ELECTRE I, ELECTRE II, ELECTRE III, ELECTRE IV, ELECTRE IS, ELECTRE TRI yöntemleri geliştirilmiştir (Tzeng ve Huang, 2011, s. 8).

\section{ELECTRE Yöntemi'nin Adımları:}

\section{Adım: Karar Matrisinin Oluşturulması}

Karar matrisinin satırlarında alternatifler, sütunlarında ise kriterler yer alır.

\section{Adım: Normalize Edilmiş Karar Matrisinin Oluşturulması}

Maliyet ve fayda kriteri için normalizsayon formülleri eşitlik 7 ve 8 yardımıyla hesaplanır.

$$
\begin{aligned}
\mathrm{rij} & =\frac{\mathrm{aij}}{\sqrt{\sum_{\mathrm{k}=1}^{\mathrm{m}}(\mathrm{aij} 2)}} \quad \mathrm{i}=1,2, \mathrm{k}, \ldots . . \mathrm{m} \quad \mathrm{j}=1,2, \mathrm{k}, \ldots \mathrm{n} \\
\mathrm{rij} & =\frac{1 / \mathrm{aij}}{\sqrt{\sum_{\mathrm{k}=1}^{\mathrm{m}}\left(\frac{1}{\mathrm{aij}}\right) 2}} \mathrm{i}=1,2, \mathrm{k}, \ldots . \mathrm{m} \mathrm{j}=1,2, \mathrm{k}, \ldots . \mathrm{n}
\end{aligned}
$$

\section{Adım: Ağırlıklı Normalize Karar Matrisinin Oluşturulması}

Normalize edilen matrisinin her bir sütunundaki değerler ağırlık (w) değeri ile çarpıllp ağırlıklı normalize matris elde edilir.

\section{Adım: Uyum ve Uyumsuzluk Kümelerinin Belirlenmesi}

$\mathrm{Y}$ matrisinde karar noktaları birbirleriyle değerlendirme faktörleri açısından kıyaslanır. Aa ve $\mathrm{Ab}$ $(1,2, \mathrm{k}, \mathrm{m}$ ve $\mathrm{p} \neq \mathrm{q})$ uyum kümesinde $\mathrm{Aa}$ ve $\mathrm{Ab}$ alternatifine göre seçilir.

$$
\mathrm{C}(\mathrm{a}, \mathrm{b})=\left\{j \mid V_{a j} \geq V_{b j}\right\}
$$

Aa ve Ab' den daha kötü bir alternatif ise uyumsuzluk kümesi oluşturulur. Daha sonra uyum kümesi kadar uyumsuzluk kümesi bulunur.

$$
\mathrm{D}(\mathrm{a}, \mathrm{b})=\left(\mathrm{j}, V_{a j}<V_{b j}\right)
$$




\section{Adım: Uyum ve Uyumsuzluk Indekslerinin Hesaplanması}

Uyum matrisinin $(C)$ oluşturulması için uyum kümeleri göz önünde bulundurulur. C matrisinin elemanları eşitlik 11 ile hesaplanır.

$$
C a b=\Sigma j * W j *
$$

Uyumsuzluk matrisinin (D) elemanları eşitlik 12 yardımıyla hesaplanır:

$$
D_{a b}=\frac{\operatorname{Max}\left(\Sigma \mid \mathbf{j}=0 \mathrm{Vaj}_{0}-\mathrm{Vb}_{0}\right)}{\operatorname{Max}\left(\Sigma \mid \mathrm{Vaj}_{0}-\mathrm{Vbj}\right)}
$$

jo, uyumsuzluk kümesi D (a,b)'de yer alan faktörlerdir.

\section{Adım: Üstünlük Karşılaştırması Yapılması}

$\mathrm{C}$ ve $\mathrm{D}$ değerlerinin ortalamaları alınır. $\mathrm{C}$ ab $\geq \mathrm{C}$ ve

$$
\begin{aligned}
C & =\Sigma \Sigma c(a, b) / m(m-1) \\
f(a, b)=1 & \text { e ğer } c(a, b) \geq C, \quad f(a, b)=0 \text { e } \breve{g} \operatorname{er} c(a, b)<C \\
D & =\frac{\sum_{\mathrm{a}=1}^{\mathrm{m}} \quad \sum_{\mathrm{bd}(\mathrm{a}, \mathrm{b})}^{\mathrm{m}}}{\mathrm{m}(\mathrm{m}-1)}
\end{aligned}
$$

Uyumsuzluk indeks matrisi: $f(a, b)=1$ ĕger $d(a, b) \geq D, f(a, b)=0$ e $\breve{g}$ er $d(a, b)<D$

\section{Adım: Net Uyum ve Uyumsuzluk İndeksleri Hesaplanması}

Net uyum (Ci) ve uyumsuzluk (Di) indeksleri hesaplanmasının ardından (Ci) değerleri büyükten küçüğe, (Di) değerleri ise küçükten büyüğe sıralanır (Serinkaya, 2001, s. 32).

$$
\begin{aligned}
& \mathrm{Ca}=\sum_{b=1}^{m} \mathrm{C}(\mathrm{a}, \mathrm{b})-\sum_{b=1}^{m} \mathrm{C}(\mathrm{b}, \mathrm{a}) \\
& \mathrm{Da}=\sum_{b=1}^{m} \mathrm{D}(\mathrm{a}, \mathrm{b})-\sum_{b=1}^{m} \mathrm{D}(\mathrm{b}, \mathrm{a})
\end{aligned}
$$

\section{Evren - Örneklem}

Araştırmanın evrenini, Muğla'nın Menteşe, Ortaca, Fethiye, Dalaman, Seydikemer, Yatağan, Kavaklıdere, Datça ve Ula ilçelerinde Dijital Bankacilık ürünleri kullanan banka müşterileri oluşturmaktadır. 01/01/2020-29/02/2020 tarihleri arasında uygulanan anket çalışması ile bankaların Dijital Bankacılık ürünlerini kullanan müşterilerin memnuniyetlerini ölçmek amacıyla, örnek büyüklüğünün tespit edilmesinde kolayda örnekleme yöntemi kullanılmıştır. Dijital bankacıllk ürünlerini kullanan banka müşterilerinden 350 katılımcıya anketler yüz yüze uygulanmış, katılımcılardan 80' i dijital bankacılık ürünleri kullanmadıkları için, 100' ü de bankaların maaş müşterisi oldukları için yani zorunlu olarak söz konusu bankalarla işlem yaptıkları için analize dahil edilmemişlerdir. Kalan 170 katılımcının anket sorularına vermiş oldukları cevaplar üzerinden analizler yapılmıştır.

\section{Veri Toplama Araçları}

Veri toplama aracı olarak anket uygulaması yapılmıştır. Ankette demografik bilgilerinin yanında, Parasuraman, Zeithaml ve Berry tarafindan SERVQUAL Yöntemi kullanılmıstır. Yönteme göre ankete konu olan hizmet kalitesi kriterleri: işlem hızı, güven, görsellik, imaj, yenilikçilik, bilgilendirme, bütünlük, üstünlük ve anlaşılabilirlik kriterleri ile ilgili ikili karşılaştırmalar, 0-9 arası puanlama yapmaları istenmiştir, hesaplamalarda kullanılan kriter ağırlıklanı, bu puanlamalar doğrultusunda gerçekleştirilmiştir. Anket sorularının uygulanabilirliği ile ilgili 40 kişiye pilot uygulama yapılmış, anlaşılmakta güçlük çekilen ifadeler değiştirilmiş ve anket formu son haline getirilmiştir. Analize dahil edilen bankalar: Finansbank, Akbank, T. İş Bankası, Garanti BBVA Bankası, Ziraat Bankası, Yapı Kredi Bankası ve Halkbank'tır. 7 alternatif banka karışık olarak A1, A2, A3, A4, A5, A6 ve A7 olarak kodlanmıştır.

\section{Verilerin Analizi}

Çalışmada ÇKKV Yöntemleri'nden Analitik Hiyerarşi Prosesi (AHP) temelli MOORA ve ELECTRE yöntemleri kullanılarak Dijital Bankacıllk ürünlerini kullanan banka müşterilerinin 
memnuniyetleri ölçülmüştür. Kriterlerin ağırlıklandırılmasının objektif olması açısından AHP yöntemi ile yapılmıştır. Analizler Microsoft Excel programı yardımıyla yapılmıştır.

\section{Bulgular}

Tablo 2. Katılimularn Demografik Bilgileri

\begin{tabular}{|c|c|c|c|c|c|c|c|c|}
\hline Cinsiyet & Frekans & Yüzde & $\begin{array}{l}\text { Medeni } \\
\text { Durum }\end{array}$ & Frekans & Yüzde & Banka & Frekans & Yüzde \\
\hline Kadin & 83 & 48,8 & Bekar & 63 & 37,1 & Finansbank & 24 & 14,1 \\
\hline \multirow[t]{2}{*}{ Erkek } & 87 & 51,2 & Evli & 105 & 61,8 & Garanti Bank & 30 & 17,6 \\
\hline & & & Boşanmış & 2 & 1,2 & Y.K.B. & 25 & 14,7 \\
\hline Yaş & & & & & & Akbank & 25 & 14,7 \\
\hline 25 yaş altı & 15 & 9 & Eğitim & & & Ziraat B. & 24 & 14,1 \\
\hline $26-35$ aras1 & 50 & 31,5 & Lise & 46 & 27,1 & Halk B. & 12 & 7,1 \\
\hline $36-45$ aras1 & 54 & 31,5 & Lisans & 9 & 5,3 & İş Bankası & 30 & 17,6 \\
\hline 46-55 aras1 & 18 & 10 & Önlisans & 102 & 60 & & & \\
\hline 56-65 aras1 & 26 & 16 & Y. Lisans & 11 & 6,5 & Süre & & \\
\hline \multirow[t]{2}{*}{65 yaş üstü } & 7 & 2 & Doktora & 2 & 1,1 & $1-3$ y1l & 31 & 18,2 \\
\hline & & & & & & $4-7 \mathrm{y} 1 \mathrm{l}$ & 71 & 41,8 \\
\hline İlçe & & & Meslek & & & $8-11$ yll & 53 & 31,2 \\
\hline Fethiye & 30 & 17,6 & Öğrenci & 11 & 6,5 & 12 y1l ve üzeri & 15 & 8,8 \\
\hline Seydikemer & 20 & 11,8 & Öğretmen & 22 & 12,9 & & & \\
\hline Dalaman & 14 & 8,2 & Memur & 11 & 6,5 & Sebep & & \\
\hline Ortaca & 15 & 8,8 & Emekli & 35 & 20,6 & Masrafsiz & 25 & 14,5 \\
\hline Ula & 10 & 5,9 & İşçi & 27 & 15,9 & Güven & 27 & 17 \\
\hline Köyceğiz & 14 & 8,2 & Ev Hanımı & 8 & 4,7 & Alışkanlık & 14 & 6,5 \\
\hline Yatağan & 14 & 8,2 & Mühendis & 12 & 7,1 & Hizlı & 42 & 25 \\
\hline Menteşe & 35 & 20,6 & Esnaf & 44 & 25,8 & Kullanışlı & 43 & 26 \\
\hline Datça & 18 & 10,6 & & & & Tanıdık var & 19 & 11 \\
\hline Gelir & & & S1kl1k & & & & & \\
\hline 2500 ve alt1 & 33 & 19,3 & Hergün & 98 & 57,7 & Zaman Dilimi & & \\
\hline $2501-3500$ & 40 & 23,6 & 2 günde 1 & 13 & 7,6 & Sabah & 75 & 44,1 \\
\hline $3501-4500$ & 21 & 9,4 & Haftada 2 & 23 & 13,5 & Öğleden Sonra & 59 & 34,7 \\
\hline $4501-5500$ & 39 & 25,7 & Haftada 1 & 16 & 9,4 & Akşam & 36 & 21,2 \\
\hline $5501-6500$ & 10 & 5,9 & Ayd 1 & 20 & 11,8 & & & \\
\hline $6501-7500$ & 4 & 2,4 & & & & & & \\
\hline 7500 ve üzeri & 23 & 13,7 & & & & & & \\
\hline
\end{tabular}

Tablo 2'de anket uygulaması ile elde edilen katılımciların demografik bilgileri yer almaktadır. Buna göre: katılımcıların cinsiyet dağılımlarının birbirlerine yakın olup, evli olanların (\%61,8), 25-45 yaş aralı̆̆ında olanların $(\% 31,50)$, ön lisans mezunlarının (\%60) çoğunlukta olduğu, çalısıllan bankaların sayılarının birbirine yakın dağılım gösterdiği, en çok işlem yapılan bankaların az farkla Garanti BBVA ve İş Bankası (\%17,6) olduğu, en çok Menteşe ilçesinden katılımın gerçekleştiği (\%20,6), meslek olarak esnafların (\%25,8) çoğunluğu oluşturduğu, banka ile çalışma sürelerinin en çok 4-7 y1l (\%41,8) olduğu, gelir seviyelerinin 2501-3500 lira arasında olduğu (\%40), işlem yapma sıklıklarının her gün $(\% 57,7)$ olduğu katılımcıların çoğunlukla sabah saatlerinde $(\% 44,1)$ işlem yaptıkları ve çalısıllan bankayı seçme sebeplerinin 'kolay kullanılabilirlik' özelliği olduğu sonuçlarına varılmıştır.

AHP ile ağırlıkların hesaplanması sonucu Tablo 3 'teki değerler elde edilmiştir.

Tablo 3. AHP Yöntemi ile Hesaplanan Kriter Ağrrlklan

\begin{tabular}{|c|c|c|c|c|c|c|c|c|c|}
\hline & $\mathrm{Kl}$ & $\mathrm{K} 2$ & $\mathrm{~K} 3$ & $\mathrm{~K} 4$ & $\mathrm{~K} 5$ & $\mathrm{~K} 6$ & $\mathrm{~K} 7$ & $\mathrm{~K} 8$ & K9 \\
\hline Kritterler & Isslem Hizı & Güren & Götsellik & Imaj & Yenilikcillik & Bilgilenditime & Bütünliuk & Üstunlïk & Anlasslabilitilitk \\
\hline Ağrtilklar & $10,10 \%$ & $23,58 \%$ & $7,12 \%$ & $8,48 \%$ & $8,97 \%$ & $0,51 \%$ & 0,50\% & $10,32 \%$ & $12,42 \%$ \\
\hline
\end{tabular}

Tablo 3 'teki kriter ağırlıkları incelendiğinde; 'güven' kriteri $(\% 23,58)$ ilk sırada yer almaktadır. Daha sonra 'anlaşılabilirlik' $(\% 12,42)$, 'üstünlük' $(\% 10,32)$, 'işlem hız1' $(\% 10,10)$, 'bilgilendirme' $(\% 9,51)$, 'bütünlük' (\%9,50), 'yenilikçilik' (\%8,97), 'imaj' (\%8,48), 'görsellik' $(7,12)$ kriterleri takip etmektedir. 


\section{MOORA Analizi Sonucu Elde Edilen Bulgular}

\section{MOORA Oran Yöntemi ile Sıralama}

Tablo 4. Dijital Bankacllk. Ürünleri Kullammınn Müssteri Memnuniyetine Ait Veri Seti

\begin{tabular}{|c|c|c|c|c|c|c|c|c|c|}
\hline & Işlem Hızı & Güven & Görsellik & Imaj & Yenilikçilik & Bilgilendirme & Bütünlük & Ustünlük & Anlaş11abilirlik \\
\hline A1 & 0,0862 & 0,1817 & 0,0331 & 0,0336 & 0,0467 & 0,0689 & 0,0709 & 0,0870 & 0,1415 \\
\hline A2 & 0,0811 & 0,2458 & 0,0269 & 0,0451 & 0,0523 & 0,0599 & 0,0583 & 0,0640 & 0,0815 \\
\hline A3 & 0,0569 & 0,1402 & 0,0415 & 0,0399 & 0,0549 & 0,0713 & 0,0645 & 0,0726 & 0,1093 \\
\hline A4 & 0,0663 & 0,1961 & 0,0372 & 0,0348 & 0,0403 & 0,0727 & 0,0570 & 0,0717 & 0,1077 \\
\hline A5 & 0,0856 & 0,2307 & 0,0326 & 0,0407 & 0,0469 & 0,0568 & 0,0601 & 0,0677 & 0,0965 \\
\hline A6 & 0,0462 & 0,2444 & 0,0282 & 0,0388 & 0,0704 & 0,0684 & 0,0515 & 0,0638 & 0,0887 \\
\hline A7 & 0,0726 & 0,1667 & 0,0333 & 0,0501 & 0,0517 & 0,0611 & 0,0686 & 0,0853 & 0,1196 \\
\hline Ağırlıklar & $10,10 \%$ & $23,58 \%$ & $7,12 \%$ & $8,48 \%$ & $8,97 \%$ & $9,51 \%$ & $9,50 \%$ & $10,32 \%$ & $12,42 \%$ \\
\hline
\end{tabular}

Tablo 4'te eşitlik 1 yardımıyla katılımcıların anket sorularına verdikleri cevapların geometrik ortalamaları hesaplanmıs, veri seti oluşturulmuştur.

Tablo 5. Normalize Matrisin Ağrrlkelandirlması

\begin{tabular}{cccccccccc}
\hline & K1 & K2 & K3 & K4 & K5 & K6 & K7 & K8 \\
\hline A1 & 0,452 & 0,336 & 0,373 & 0,312 & 0,336 & 0,396 & 0,433 & 0,446 & 0,495 \\
A2 & 0,425 & 0,455 & 0,302 & 0,418 & 0,375 & 0,344 & 0,356 & 0,356 \\
A3 & 0,298 & 0,259 & 0,467 & 0,370 & 0,394 & 0,410 & 0,394 & 0,394 \\
A4 & 0,348 & 0,363 & 0,419 & 0,323 & 0,290 & 0,417 & 0,348 & 0,348 \\
A5 & 0,449 & 0,427 & 0,368 & 0,378 & 0,337 & 0,326 & 0,367 & 0,367 & 0,394 \\
A6 & 0,242 & 0,452 & 0,317 & 0,359 & 0,506 & 0,393 & 0,315 & 0,315 \\
A7 & 0,381 & 0,308 & 0,375 & 0,464 & 0,371 & 0,351 & 0,419 & 0,419 & 0,537 \\
Ağırl1klar & $10,10 \%$ & $23,58 \%$ & $7,12 \%$ & $8,48 \%$ & $8,97 \%$ & $9,51 \%$ & $9,50 \%$ & $10,32 \%$ & $12,42 \%$ \\
\hline
\end{tabular}
edilmiştir.

Tablo 5, eşitlik 2 ile karar matrisinin AHP yöntemi ile hesaplanan ağırlıklar ile çarpılması sonucu elde

Tablo 6. MOORA Oran Yöntemi ile Siralama Sonuclar

\begin{tabular}{cccccccccccc}
\hline & Maks. & Maks. & Maks. & Maks. & Maks. & Maks. & Maks. & Maks. & Maks. \\
\hline & K1 & K2 & K3 & K4 & K5 & K6 & K7 & K8 & K9 & y1 & Siralama \\
A1 & 0,046 & 0,079 & 0,027 & 0,026 & 0,030 & 0,038 & 0,041 & 0,046 & 0,061 & 0,394 & 7 \\
A2 & 0,043 & 0,107 & 0,022 & 0,035 & 0,034 & 0,033 & 0,034 & 0,037 & 0,047 & 0,391 & 6 \\
A3 & 0,030 & 0,061 & 0,033 & 0,031 & 0,035 & 0,039 & 0,037 & 0,041 & 0,049 & 0,357 & 2 \\
A4 & 0,035 & 0,086 & 0,030 & 0,027 & 0,026 & 0,040 & 0,033 & 0,036 & 0,036 & 0,348 & 1 \\
A5 & 0,045 & 0,101 & 0,026 & 0,032 & 0,030 & 0,031 & 0,035 & 0,038 & 0,042 & 0,380 & 4 \\
A6 & 0,024 & 0,107 & 0,023 & 0,030 & 0,045 & 0,037 & 0,030 & 0,032 & 0,063 & 0,392 \\
A7 & 0,038 & 0,073 & 0,027 & 0,039 & 0,033 & 0,033 & 0,040 & 0,043 & 0,046 & 0,373 \\
\hline
\end{tabular}

Tablo 6'da bankaların müşteri memnuniyetlerinin, MOORA Oran Yöntemi ile A4, A3, A7, A1, A4, A6, A2 olarak sıralanmıştır. Yönteme göre A3 bankasının dijital bankacılık müşteri memnuniyeti konusunda diğer bankalardan daha avantajlı durumda olduğu görülmektedir.

\section{MOORA Referans Noktası Yöntemi ile Siralama}

Tablo 7. Referans Noktalarmin Bulunmast

\begin{tabular}{cccccccccc}
\hline & K1 & K2 & K3 & K4 & K5 & K6 & K7 & K8 & K9 \\
\hline A1 & 0,0862 & 0,1817 & 0,0331 & 0,0336 & 0,0467 & 0,0689 & 0,0709 & 0,0870 \\
A2 & 0,0811 & 0,2458 & 0,0269 & 0,0451 & 0,0523 & 0,0599 & 0,0583 & 0,0640 & 0,1415 \\
A3 & 0,0569 & 0,1402 & 0,0415 & 0,0399 & 0,0549 & 0,0713 & 0,0645 & 0,0726 \\
A4 & 0,0663 & 0,1961 & 0,0372 & 0,0348 & 0,0403 & 0,0727 & 0,0570 & 0,0717 \\
A5 & 0,0856 & 0,2307 & 0,0326 & 0,0407 & 0,0469 & 0,0568 & 0,0601 & 0,0677 \\
A6 & 0,0462 & 0,2444 & 0,0282 & 0,0388 & 0,0704 & 0,0684 & 0,0515 & 0,0638 \\
A7 & 0,0726 & 0,1667 & 0,0333 & 0,0501 & 0,0517 & 0,0611 & 0,0686 & 0,0853 & 0,0965 \\
Referans & 0,0862 & 0,2458 & 0,0415 & 0,0501 & 0,0704 & 0,0727 & 0,0709 & 0,0870 \\
Noktalar1 & & & & & & & 0,1196 \\
\hline
\end{tabular}

Tablo 7'de eşitlik 3 ve 4 ile kriterlerin tamamının maksimum değer alması beklendiği için referans noktaları maksimum değerler olarak belirlenmiştir. 
NOYAN ve GAVCAR

Dijital Bankacılıkta Müşteri Memnuniyetinin Çok Kriterli Karar Verme Yöntemleri ile Değerlendirilmesi

Tablo 8. MOORA Referans Noktası Yöntemi ile Siralama Sonuçları

\begin{tabular}{ccccccccccccc}
\hline & K1 & K2 & K3 & K4 & K5 & K6 & K7 & K8 & K9 & Maks'lar & Siralama \\
\hline A1 & 0,000 & 0,064 & 0,008 & 0,016 & 0,024 & 0,004 & 0,000 & 0,000 & 0,022 & 0,064 & 3 \\
A2 & 0,005 & 0,000 & 0,015 & 0,005 & 0,018 & 0,013 & 0,013 & 0,023 & 0,038 & 0,038 & 7 \\
A3 & 0,029 & 0,106 & 0,000 & 0,010 & 0,016 & 0,001 & 0,006 & 0,014 & 0,010 & 0,106 & 1 \\
A4 & 0,020 & 0,050 & 0,004 & 0,015 & 0,030 & 0,000 & 0,014 & 0,015 & 0,012 & 0,050 & 4 \\
A5 & 0,001 & 0,015 & 0,009 & 0,009 & 0,024 & 0,016 & 0,011 & 0,019 & 0,023 & 0,024 & 6 \\
A6 & 0,040 & 0,001 & 0,013 & 0,011 & 0,000 & 0,004 & 0,019 & 0,023 & 0,031 & 0,040 & 5 \\
A7 & 0,014 & 0,079 & 0,008 & 0,000 & 0,019 & 0,012 & 0,002 & 0,002 & 0,000 & 0,079 & 2 \\
\hline
\end{tabular}

Tablo 8'de eşitlik 5 ve 6 yardımıla bankaların müşteri memnuniyetlerinin, MOORA Referans Noktası Yöntemi ile sıralanması A3, A7, A1, A4, A6, A5 ve A2 şeklindedir. Yönteme göre A3 bankasının dijital bankacılık müşteri memnuniyeti konusunda diğer bankalardan daha avantajlı durumda olduğu görülmektedir.

\section{ELECTRE Analizi Sonucu Elde Edilen Bulgular}

Tablo 9. Karar Matrisinin Normalize Edilmesi

\begin{tabular}{ccccccccccc}
\hline & K1 & K2 & K3 & K4 & K5 & K6 & K7 & K8 & K9 \\
\hline A1 & 0,452 & 0,953 & 0,174 & 0,176 & 0,245 & 0,361 & 0,371 & 0,456 & 0,742 \\
A2 & 0,425 & 1,288 & 0,141 & 0,236 & 0,274 & 0,314 & 0,305 & 0,336 \\
A3 & 0,298 & 0,735 & 0,217 & 0,209 & 0,288 & 0,374 & 0,338 & 0,380 \\
A4 & 0,348 & 1,028 & 0,195 & 0,182 & 0,211 & 0,381 & 0,299 & 0,376 \\
A5 & 0,449 & 1,209 & 0,171 & 0,213 & 0,246 & 0,298 & 0,315 & 0,355 & 0,564 \\
A6 & 0,242 & 1,281 & 0,148 & 0,203 & 0,369 & 0,358 & 0,270 & 0,335 & 0,465 \\
A7 & 0,381 & 0,874 & 0,175 & 0,263 & 0,271 & 0,320 & 0,359 & 0,447 & 0,627 \\
\hline
\end{tabular}

Tablo 9'da eşitlik 7 kullanılarak karar matrisi normalize edilmiştir.

Tablo 10. Normalize Edilen Karar Matrisinin Ă̆ırlılandırlması

\begin{tabular}{|c|c|c|c|c|c|c|c|c|c|}
\hline wj & $10,10 \%$ & $23,58 \%$ & $7,12 \%$ & $8,48 \%$ & $8,97 \%$ & $9,51 \%$ & $9,50 \%$ & $10,32 \%$ & $12,42 \%$ \\
\hline & $\mathrm{K} 1$ & K2 & K3 & K4 & K5 & K6 & K7 & K8 & K9 \\
\hline A1 & 0,046 & 0,225 & 0,012 & 0,015 & 0,022 & 0,032 & 0,033 & 0,041 & 0,067 \\
\hline A2 & 0,043 & 0,304 & 0,010 & 0,020 & 0,025 & 0,028 & 0,027 & 0,030 & 0,038 \\
\hline A3 & 0,030 & 0,173 & 0,015 & 0,018 & 0,026 & 0,034 & 0,030 & 0,034 & 0,051 \\
\hline A4 & 0,035 & 0,242 & 0,014 & 0,015 & 0,019 & 0,034 & 0,027 & 0,034 & 0,051 \\
\hline A5 & 0,045 & 0,285 & 0,012 & 0,018 & 0,022 & 0,027 & 0,028 & 0,032 & 0,045 \\
\hline A6 & 0,024 & 0,302 & 0,011 & 0,017 & 0,033 & 0,032 & 0,024 & 0,030 & 0,042 \\
\hline A7 & 0,038 & 0,206 & 0,012 & 0,022 & 0,024 & 0,029 & 0,032 & 0,040 & 0,056 \\
\hline
\end{tabular}

Tablo 10'da normalize edilen karar matrisine AHP yöntemi ile elde edilen ağırlıklar eklenmiştir.

Tablo 11. Uyum Seti

\begin{tabular}{lclccccc}
\hline & & & & & & & \\
\hline C12 & $(1,3,6,8,9)$ & C21 & $(2,4,5)$ & C31 & $(3,4,5,6)$ & C41 & $(2,3,4,6)$ \\
C13 & $(1,2,7,8,9)$ & C23 & $(1,2,4)$ & C32 & $(3,5,6,7,8,9)$ & C42 & $(3,6,7,8,9)$ \\
C14 & $(3,5,7,8,9)$ & C24 & $(1,2,4,5,7)$ & C34 & $(3,4,5,7,8,9)$ & C43 & $(1,2,6,9)$ \\
C15 & $(1,3,5,6,7,8,9)$ & C25 & $(1,3,5,6,7,8,9)$ & C35 & $(3,4,5,6,7,8,9)$ & C45 & $(3,6,8,9)$ \\
C16 & $(1,2,6,7,8,9)$ & C26 & $(1,2,4,7,8)$ & C36 & $(1,3,4,6,7,8,9)$ & C46 & $(1,3,6,7,8,9)$ \\
C17 & $(2,3,6,7,8,9)$ & C27 & $(1,2,5,6)$ & C37 & $(3,5,6)$ & C47 & $(2,3,6)$ \\
& & & & & & & \\
C51 & $(1,2,4,5)$ & C61 & $(2,4,5,6)$ & C71 & $(3,4,5)$ & & \\
C52 & $(1,3,7,8,9)$ & C62 & $(3,5,6,8,9)$ & C72 & $(3,4,5,6,7,8,9)$ & & \\
C53 & $(1,2,4)$ & C63 & $(2,4,5)$ & C73 & $(1,2,4,7,8,9)$ & & \\
C54 & $(1,2,4,5,7)$ & C64 & $(2,4,5)$ & C74 & $(1,3,4,5,7,8,9)$ & & \\
C56 & $(1,3,4,7,8,9)$ & C65 & $(2,3,4,5,6)$ & C75 & $(3,4,5,6,7,8)$ & & \\
C57 & $(1,2)$ & C67 & $(2,5,6)$ & C76 & $(1,3,4,7,8,9)$ & & \\
\hline
\end{tabular}


Tablo 12. Uyumsuఇluk Seti

\begin{tabular}{|c|c|c|c|c|c|c|c|}
\hline \multicolumn{8}{|c|}{ Uyumsuzluk Seti } \\
\hline D12 & $(2,5)$ & $\mathrm{D} 21$ & $(1,3,6,7,8,9)$ & D31 & $(1,2,7,8,9)$ & D41 & $(1,5,7,8,9)$ \\
\hline D13 & $(3,4,5,6)$ & D23 & $(3,5,6,7,8,9)$ & D32 & $(1,2)$ & D42 & $(1,2,5)$ \\
\hline D14 & $(1,2,4,6)$ & D24 & $(3,6,8,9)$ & D34 & $(1,2,4,6)$ & D43 & $(3,4,5,7,8)$ \\
\hline D15 & 2 & D25 & 2 & D35 & $(1,2)$ & D45 & $(1,2,4,5,7)$ \\
\hline D16 & $(3,4,5)$ & D26 & $(3,5,6,9)$ & D36 & $(2,5)$ & D46 & $(2,4,5)$ \\
\hline D17 & $(1,4,5)$ & $\mathrm{D} 27$ & $(3,4,7,8,9)$ & D37 & $(1,2,4,7,8,9)$ & D47 & $(1,4,5,7,8,9)$ \\
\hline D51 & $(3,6,7,8,9)$ & D61 & $(1,3,7,8,9)$ & D71 & $(1,2,6,7,8,9)$ & & \\
\hline D52 & $(2,4,5,6)$ & D62 & $(1,2,4,7)$ & D72 & $(1,2)$ & & \\
\hline D53 & $(3,5,6,7,8,9)$ & D63 & $(1,3,6,7,8,9)$ & D73 & $(3,5,6)$ & & \\
\hline D54 & $(3,6,8,9)$ & D64 & $(1,3,6,7,8,9)$ & D74 & $(2,6)$ & & \\
\hline D56 & $(2,5,6)$ & D 65 & $(1,7,8,9)$ & D75 & $(1,2,9)$ & & \\
\hline D57 & $(3,4,5,6,7,8,9)$ & D67 & $(1,3,4,7,8,9)$ & D76 & $(2,5,6)$ & & \\
\hline
\end{tabular}

Tablo 11 ve tablo 12 'de uyumluluk ve uyumsuzluk kümelerini ve matrisleri eşitlik 11 ve 12 yardımıyla oluşturulmuştur. ELECTRE Yöntemi'nin diğer yöntemlerden farklı olarak tüm alternatiflerin ikili kombinasyonlarla karşılaştırılmaları yoluyla alternatifler arası uyumluluk ve uyumsuzluk üstünlük kümelerinin hesaplanması, matrislerin eşik değerlerinin elde edilmesidir (Çelikbilek, 2018, s. 216). Elde edilen matrislerden ortak olarak koşulları sağlayan yani '1'değerini aynı anda alan hücrelerden oluşan alternatif çiftleri elde edilir. Alternatif çiftler için çekirdek çözüm elde edilir. Hesaplanan değerler büyükten küçüğe doğru sıralanır (Milani vd., 2006, s. 1-19). Her iki listede de ilk sırada yer alan alternatif, en ideal alternatif olarak kabul edilir.

Tablo 13. Uyumluluk ve Uyumsu₹luk Değerlerinin Siralamast

\begin{tabular}{ccccc}
\hline \multicolumn{7}{c}{ Uyumluluk ve Uyumsuzluk Değerlerinin Hesaplanmas1 } & \\
\hline \multicolumn{7}{c}{ Ci } & Siralama & Di & Siralama \\
\hline A1 & 1,2950 & 1 & $-2,5912$ & 1 \\
A2 & $-0,3406$ & 5 & $-1,2461$ & 2 \\
A3 & 0,1698 & 3 & 3,2895 & 7 \\
A4 & $-0,3259$ & 4 & 0,8207 & 5 \\
A5 & $-0,4015$ & 6 & 0,5316 & 4 \\
A6 & $-1,1756$ & 7 & $-0,7167$ & 3 \\
A7 & 0,1973 & 2 & 1,6628 & 6 \\
\hline
\end{tabular}

Tablo 13 'te eşitlik 15 ve 16 kullanılarak bankaların müşteri memnuniyetleri, ELECTRE yöntemi ile sıralamanın maksimum $\mathrm{C} 1=1,2950$ ve minimum $\mathrm{D} 1=-2,5912$ değerleri ile müşteri memnuniyeti en yüksek değerlere sahip olan banka $A 1$, en düşük değerlere sahip olan banka ise A6 olarak bulunmuştur. ELECTRE yöntemi ile sıralama: A1, A7, A3, A4, A2, A5 ve A6 şeklindedir. Yönteme göre A1 bankasının dijital bankacılık ürünleri, müşteri memnuniyeti konusunda diğer bankalardan daha avantajlı durumda olduğu görülmektedir.

\section{Tartı̧̧ma, Sonuç ve Öneriler}

Dijitalleşme yarışının giderek hız kazandığı günümüz bilgi çağında bankalar müşterilerinin memnuniyetlerini kazanmaya çalışmalı, hizmet kalitelerini ise üst düzeylere taşımalılardır. Müşteriler için banka seçimi bir karar problemi oluşturmaktadır. Bu çalışmada kriterler ÇKKV yöntemlerinden AHP yöntemi ile ağırlıklandırılıp ELECTRE ve MOORA yöntemleri ile dijital bankacılık ürünleri kullanan müşterilerin memnuniyetlerine etki eden kriterlerin ve alternatif bankaların sıralaması yapılmıştır. Belirlenen alternatif 7 adet banka bu kapsamda değerlendirilmiştir. 9 adet kriter önem sırasına göre uygulanan anket sorularındaki ikili karşılaştırmalar yardımıyla analizler yapılmıştır. Verilen cevaplar MOORA ve ELECTRE yöntemleri ile uyum ve uyumsuzluk matrisleri oluşturulmuştur. Uyum ve uyumsuzluk matrislerinin verdiği sonuçlara göre, net en üst değerler ve net en alt değerler belirlenerek, müşterilerin bankaların dijital bankacılık ürünlerinden memnun olup olmadıklanı değerlendirilmiş bu doğrultuda sıralamalar yapılmıştır. 170 katılımcının anket sorularına vermiş oldukları cevaplar değerlendirilmiştir. Analize dahil edilen bankalar: Finansbank, Akbank, T. İş Bankası, Garanti BBVA Bankası, Ziraat Bankası, Yapı Kredi Bankası ve Halkbank'tır. 7 adet alternatif banka karışık olarak A1, A2, A3, A4, A5, A6 ve A7 olarak kodlanmıştır. Analizde kullanılan kriterler ise güven, anlaşlabilirlik, üstünlük, işlem hızı, bilgilendirme, bütünlük, yenilikçilik, imaj ve görselliktir. AHP yöntemi ile belirlenen 
ağırlıklandırma sonucu en yüksek ağırlıklı kriterin 'güven' kriteri $(\% 23,58)$ olduğu, daha sonra ise 'anlaşılabilirlik' (\%12,42), 'üstünlük' (\%10,32), 'işlem hız1' (\%10,10), 'bilgilendirme' (\%9,51), 'bütünlük' $(\% 9,50)$, 'yenilikçilik' $(\% 8,97)$, 'imaj' $(\% 8,48)$, 'görsellik' $(\% 7,12)$ kriterlerinin sıralandı̆̆1 görülmektedir.

Yapilan analizler sonucu:

ELECTRE yöntemi ile müşteri memnuniyeti sıralaması: A1, A7, A3, A4, A2, A5 ve A6,

MOORA Referans Noktası yöntemi ile sıralama: A3, A7,A1, A4, A6, A5 ve A2,

MOORA Oran yöntemi ile siralama ise: A4, A3, A7, A1, A4, A6, A5 ve A2 şeklinde olduğu ve sıralamaların birbirlerine benzerlik gösterdiği, A3 ve A7 bankalarının müşteri memnuniyetlerinin daha yüksek olduğu görülmektedir.

Yapılan diğer çalışmalar incelendiğinde; Gonzalez vd., (2004), Mukherjee ve Nath, (2003), Han ve Baek, (2004), Rod vd. (2009), Araslı vd. (2009) Ustasüleyman (2009), Pala ve Kartal (2010), Nimako vd. (2013), Orçanlı ve Özdemir, (2013), Sagib ve Zapan (2014), Gürbüz, (2019) çalışmalarındaki sonuçların (güven kriterinin müşteri memnuniyeti üzerinde önemli etkiye sahip olduğu), bu çalışmadan elde edilen sonuçlar ile paralellik göstermektedir. Bankaların, dijital bankacılık ürünlerini kullanan müşterilerinin memnuniyetlerini sağlamaları için 'güven' kriterine önem vermelerinin gerekli olduğu görülmektedir.

Çalışmanın sınırlılıkları, uygulamanın Muğla ili ve çevresine gerçekleştirilmiş olması, ÇKKV yöntemlerinden bir kaçının kullanılmasıdır. Gelecekte yapılacak olan çalışmalarda karma yöntemler tercih edilebilir ve diğer ÇKKV yöntemleri de çalışmalara dâhil edilerek sonuçlar birbirleri ile kıyaslanabilir.

Dijital bankacılık ürünlerine olan memnuniyet, bankaların hizmet kalitesi kriterlerinden en yüksek orana sahip olan 'güven' kriteri ile ilgili olarak karşılaşılan problemlerin başında müşterilerin bilgilerinin ele geçirileceği ve başka ortamlarda paylaşılacağı kaygısı gelmektedir. Bankalar bu konularda müşterilerini telkin etmeli,müşterilere yapılan her işlemle ilgili onay ve bilgilendirme mesajı göndermeli, tüm bankacılık işlemleri şeffaflık ilkesine dayanarak yapılmalı, dolandırıcılık işlemlerine karşı önlem alınmalıdır. Bankaların, müşterilerine güven vermelerinin yolları ise hizmet kalitelerini yüksek tutmaları, artan teknolojik gelişmeler ile ürünlerin, hizmetlerin müşterilerin beklentileri doğrultusunda hızlı dönüşümlerinin sağlanması ve bankaların güçlü sermaye yeterlilik oranlarına sahip olmaları yer almaktadır. Bankaların artan rekabet ve teknoloji ortamında teknolojik alt yapılarının yeterliliŭgi de banka müşterilerine güven vermek açısından önemlidir.

\section{Etik Beyan}

"Dijital Bankacıllkta Müsteri Memnuniyetinin Çok Kriterli Karar Verme Yöntemleri ile Değerlendirilmesi” başlıklı çalışmanın yazım sürecinde bilimsel kurallara, etik ve alıntı kurallarına uyulmuş; toplanan veriler üzerinde herhangi bir tahrifat yapılmamış ve bu çalışma herhangi başka bir akademik yayın ortamına değerlendirme için gönderilmemiştir.

\section{Kaynakça}

Adiloğlu, B. ve Yücel, G. (2018). Dijitalleşme muhasebe mesleği için bir tehdit mi, yoksa bir firsat mı? XX. Türkiye Muhasebe Kongresi, TÜRMOB, 5-6 Ekim 2018, İstanbul.

Amiri, A. S. F. ve Faghani, F. (2012). Mobile banking service quality and customer satisfaction, application of servqual modal. International Journal of Management and Business Research, 2(4), 351-361.

Arasli, H., Katırcioglu, S. T. ve Smadi, S. M. (2005). A comparison of service quality in the banking industry. International Journal of Bank. Marketing, 23(7), 508-526.

Bakkal, M. ve Aksüt, U. (2011).Türk bankacılık sisteminde elektronik bankacılık uygulamalar (1. Baskı). İstanbul: Hiperling Yayinlar1.

Bilir, A. (2010). Katılım bankalarında müşteri memnuniyetinin belirlenmesi üzerine Hatay ilinde bir araştırma, C.Ü. Sosyal Bilimler Enstitüsü Dergisi, 19(3), 39-62.

Brauers, W. K. M. ve Zavadskas, E. K. (2009). Project management by MULTIMOORA as an instrument for transition economies. Technological and Economic Development of Economy, 1(5), 5-24.

Brauers, W. K. M. ve Zavadskas, E. K., (2012). Robustness of MULTIMOORA: A method for multi-objective optimization. Informatica, 23(1), 1-25.

Braunschweig, T. ve Becker, B. (2004). Choosing research priorities by using the Analytic Hierarchy Process: an application to international agriculture. $R \& D$ Management, 34(1), 77-86.

Bülbül, S. (2017). Türk bankacılı sektöründe müsteri memnuniyetinin katılım ve mevduat bankalarnnda karşılaştırmalı olarak değerlendirilmesi’ (Yüksek Lisans Pojesi). Gebze Teknik Üniversitesi, İşletme Ana Bilim Dalı, Gebze. 
Cronin, J. J. ve Taylor, S. A. (1992). Measuring service quality: Are-examination and extension. Journal of Marketing, 56(3), 55-68.

Çelikbilek, Y. ve Özdemir, M. (Edt) (2018). Çok keriterli karar verme yöntemleri (1. Basım). Ankara: Nobel Yayınc1lık.

Daniel, E. (1999). Provision of electronic banking in the UK and the Republic of Ireland. International Journal of Bank Marketing, 17(2), 72-83.

Demirel, A. C. (2017). Dijital bankachlk ve Türkiye'deki mevcut durum analiæ̨i (Yüksek Lisans Tezi). Başkent Üniversitesi, Sosyal Bilimler Enstitüsü, Ankara.

Ersöz, F. ve Atav, A. (2011). Çok kriterli karar verme problemlerinde MOORA yöntemi. KHO Savunma Bilimleri Enstitüsü Harekât Araștirması.

Ertuğrul, İ. ve Sarı, G. (2019). Hizmet kalitesi ölçümünde Servqual Tekniği: bir üniversite uygulaması, Organizasyon ve Yönetim Bilimleri Dergisi, 11(1), (Online).

González, M., Quesada, G., Picado, F. ve Eckelman, C. (2004). Customer satisfaction using QFD: An e-banking case. Managing Service Quality: An International Journal, 14(4), 317-330.

Göktolga, Z. G. ve B. Gökalp (2012). İş seçimini etkileyen kriterlerin ve alternatiflerin AHP metodu ile belirlenmesi. Cumburiyet Üniversitesi. İktisadi ve İdari Bilimler Dergisi, 13(2), 75-76.

Gronroos, C., A. (1984). Service quality model and its marketing implications. European Journal of Marketing, 18(4), 36-44.

Gürbüz, M. A. (2019). Hizmet kalitesinin ölçümü ve alglanan hizmet kalitesinin yatırmo memnuniyeti ile sadakatine etkisi: türev ürün hiæmeti sağlayan bir yatırm kurulusu üzerine ampirik çalısma (Doktora Tezi). Beykent Üniversitesi, Sosyal Bilimler Enstitüsü, İssletme Yönetimi Ana Bilim Dalı, İstanbul.

Han, S. L. ve Baek, S. (2004). Antecedents and consequences of service quality in online banking: An application of the Servqual instrument in NA. Advances in Consumer Research. 31.

Karakaşoğlu, N. (2008). Bulank çok kriterli karar verme yöntemleri ve uygulama (Yüksek Lisans Tezi). Pamukkale Üniversitesi, Sosyal Bilimler Enstitüsü, Denizli.

Kenger, M. D. ve Organ, A. (2017). Banka personel seçiminin ÇKKV yöntemlerinden Entropi Temelli ARAS yöntemi ile değerlendirilmesi. Adnan Menderes Üniversitesi Sosyal Bilimler Enstitüsü Dergisi, 4(4), 152-170.

Kumarapperuma, N. K. (2014). Development of the service quality and performance model for independent colleges in the UK (PhD Thesis). Anglia Ruskin University.

Kuru, A. ve Akın, B. (2011). Entegre yönetim sistemlerinde Çok Kriterli Karar Verme tekniklerinin kullanımına yönelik yaklaşımlar ve uygulamalar. Marmara Üniversitesi, Sosyal Bilimler Enstitüsü Dergisi, 10(38), 129-144.

Mishra, A. A. (2009). A study on customer satisfaction in Indian Retail Banking. The IUP Journal of Management Research, 8(11), 45-61.

Milani, A. S., Shanian, A. ve El-Lahman, C. (2006). Using different ELECTRE methods in strategic planning in the presence of human behavioral resistance. Journal of Applied Mathematics and Decision Sciences, 1-19.

Mukherjee, A. ve Nath, P. (2003). A model of trust in online relationship banking. International Journal of Bank Marketing, 21(1), 5-15.

Nimako, S. G., Gyamfi, N. K. ve Wandaogou, M. M. (2013). Customer satisfaction with internet banking service quality in the Ghanaian banking industry. International Journal of Sccentific \& Technology Research, 2(7), July.

Orçanl, K. ve Özdemir, A. (2013). Kredi kartı seçimine yönelik bir karar modeli ve uygulama: Analitik Hiyerarşi Prosesi(AHP)-ELECTRE yöntemi. Cankır Karatekin Üniversitesi Sosyal Bilimler Enstitüsü Dergisi, 4(1), 77-106.

Ortstad, R. ve Sonono, B. (2017). The effects of the digital transformation process on banks' relationship with customers: Case study of a large Swedish Bank. (Master's Thesis). Department of Business, Uppsala University, Disciplinary Domain of Humanities and Social Sciences.

Önay, O. ve Çetin, E. (2012). Turistlik yerlerin popülaritesinin belirlenmesi: İstanbul örneği. İ.Ü. İsletme Fakültesi İsletme İktisadi Enstitüsü Yönetim Dergisi, 23(72), 90-109.

Özcan, Z. Ö. (2007). Türkiye'de elektronik bankacıllk: internet bankacılı̆ğ üzerine bir çalısma. (Yüksek Lisans Tezi). Sakarya Üniversitesi Sosyal Bilimler Enstitüsü, Sakarya.

Özyörük, B. ve Özcan, E. C. (2005). Otomotiv sektöründe tedarikçi seçimine etki eden faktörler ve tedarikçi seçimi. V. Ulusal Üretim Araştırmaları Sempozyumu, İstanbul Ticaret Üniversitesi, 25-27 Kasım 625-629.

Pala, E. ve Kartal, B. (2010). Banka müşterilerinin internet bankacılığı ile ilgili tutumlarına yönelik bir pilot araştırma. Yönetim ve Ekonomi, 17(2), 43-61.

Pararasuraman, A., Zeithaml, V. A. ve Berry, L.L. (1988). SERVQUAL: A multiple-item scale for measuring consumer perceptions of service quality. Journal of Retailing, 64(1), 12-40.

Parasuraman, A. , Zeithaml, V. A. ve Berry, L. L. (1985). A conceptual model of service quality and its implications for future research. Journal of Marketing, 49(3), 41-50.

Polyakova, O. ve Mirza, M. (2015). Perceived service quality models: are they still relevant?. The Marketing Review, 15(1), 59-82.

Rod, M., Ashill, N., Shao, J. ve Carruthers, J. (2009). An examination of the relationship between service quality dimensions, overall internet banking service quality and customer satisfaction: A New Zealand study. Marketing Intelligence \& Planning, 27(1), 103-126.

Roy, B. ve Vanderpooten, D. (1996). The European school of MCDA: emergence, basic features and current works. Journal of Multi-Criteria Decision Analysis, 5(1), 23-38.

Roland, R. T. ve Oliver, R. L. (1994). Service Quality -new directions in theory and practice. New York: Sage Publications. 
Saaty, T. L. (1990). How to make a decision: the Analytic Hierarchy Process. European Journal of Operational Research, $48,9-26$.

Saaty, T. L. ve Vargas, L. G. (2001). Models, methods, concepts \& applications of the Analytic Hierarchy Process, Massachusetts: Kluwer Academic.

Saaty, T. L. (1986). Axiomatic foundation of the Analytic Hierarchy Process. Management Science, 32(7), 841-855.

Saaty, T. L. (1977). A scaling method for priorities in hierarchical structures. Journal of Mathematical Psychology, 15(3), 234-281.

Sagib, K. G. ve Zapan, B. (2015). Bangladeshi mobile banking service quality and customer satisfaction and loyalty. Marketing \& Management, 9(3), 331-346.

Saha, P ve Zhao, Y. (2005). Relationship between online service quality and customer satisfaction: A study in internet banking. Electronic Commerce (Master Thesis).

Serinkaya, O. (2001). Cok kriterli karar destek sistemi ELECTRE yöntemleri üzerine bir uygulama (Yüksek Lisans Tezi). Gazi Üniversitesi Fen Bilimleri Enstitüsü, Ankara.

Stanujkic, D., Magdalinovic, N., Stojanovic, S. ve Jovanovic, R. (2012). Extension of ratio system part of MOORA method for solving decision-making problems with interval data. Informatica, 23(1), 141-154.

Takan, M. (2002). Bankacılık teori uygulama ve yönetim (2. Baskı). Ankara: Nobel Yayın Dağıtım.

Tütek, H., Gümüşoğlu, Ş. ve Özdemir, A. (2012). Sayısal yöntemler yönetsel yaklaşım. İstanbul: Beta Basım Yayım.

Tzeng, G. H. ve Huang, J. J. (2011). Multiple attribute decision making methods and application. USA: A Chapman \& Hall Book.

Usta, S. T. (2009). Bankacilık sektöründe hizmet kalitesinin değerlendirilmesi: AHS-TOPSİS yöntemi. Bankacılar Dergisi, 69, 33-43.

Uygurtürk, H. (2015). Bankaların internet şubelerini Bulanık MOORA yöntemi ile değerlendirilmesi. Uluslararası Yönetim Ilktisat ve Isletme Dergisi, 11(25), 115-128.

Zahedi, F. (1986). The analytic hierarchy process a survey of the method and its applications. Interface, 16-26.

https://www.garantibbvamortgage.com/dijitallesen-dunyada-dijital-bankaciligin-donusumu.aspx

https://www.tbb.org.tr/Content/Upload/istatistikiraporlar/ekler/1282/Banka_Calisan_ve_Sube_SayilariAralik_2019.pdf

https://bkm.com.tr/pos-atm-kart-sayilari/

https://www.tbb.org.tr/modules/banka-bilgileri/banka_sube_bilgileri.asp.

\section{EXTENDED ABSTRACT}

Digitalization is to reach the information with less effort by using the advanced technology of electronic systems in the society (Adiloğlu, \& Yücel 2018). Digital Banking is the delivery of all kinds of banking services to customers through computers, telephones or televisions without going to bank branches. Thus, time is saved and document processes are not required (Daniel, 1999).

Digital Banking channels: corporate distribution channels: automatic exchanging systems, electronic cash management, electronic funds transfer (EFT), international money transfer (SWIFT), electronic money transfer at the point of sale (EFTPOS); retail distribution channels are automated teller machines (ATM), plastic cards, electronic money, internet banking, telephone banking, mobile banking, SMS based applications, home and office banking, television banking, palm applications, cabin banking (KIOSK) (Bakkal \& Aksüt, 2011). Service quality models are: Scandinavian Model, American (SERVQUAL) Model and SERVPERF Model can be explained.

In this study, the satisfaction of bank customers using Digital Banking was measured by using the Analytical Hierarchy Process (AHP) based MOORA and ELECTRE methods, which are among Multi Criteria Decision Making (MCDM) Methods. In terms of the objective of the weighting of the criteria, it was made with the AHP method. MCDM Methods are simultaneous decision making of multi criteria and goals that may conflict with each other (Tütek, Gümüşoğlu, \& Özdemir, 2012). MCDM Methods are (Karakaşoğlu, 2008): Analytical Hierarchy Process (AHP), Entropy, Gray Relational Analysis (GRA), Multi Attribute Utility Theory (MAUT), Additive Ratio Assesment (ARAS), Multi-Objective Optimization on Basis of Ratio Analysis (MOORA), Elimination and Choice Translating Reality (ELECTRE), Technique for Order Preference by Similarity to Ideal Solution (TOPSIS), Preference Ranking Organization Method for Encrichment Evaluations (PROMETHEE), Vise Kriterijumska Optimizacija I Kompromisno Resenje (VIKOR), Complex Proportional Assesment (COPRAS), Utilities Additives Discriminantes (UTADIS).

The MOORA Method, the process of simultaneously choosing the best decision under certain constraints introduced by Brauersand Zavadskas for the first time in 2006, is a method of decision making in proportional analysis. Analyzes were made with the MOORA-Ratio Method and the MOORAReference Point Approach.The ELECTRE Method is based on the method introduced by Benayoun in 1966 compared to the alternatives in the order of preference and choosing them (Kuru, 2011, p. 39). Todate, ELECTRE I, ELECTRE II, ELECTRE III, ELECTRE IV, ELECTRE IS, ELECTRE TRI Methods have been developed (Tzeng, \& Huang, 2011). Inthestudy, analyzes were made based on the 
answers given by 170 participants to the survey questions. "SERVQUAL Method" developed by Parasuraman, Zeithaml and Berry was used.

The service quality criterias which are the subject of the questionnaire: transaction speed, trust, visuality, image, innovativeness, information, integrity, superiority and understandability criteria, were asked to score between $0-9$, the criterion weights used in the calculations were made in line with these scores.

The banks included in the analysis are: Finansbank, Akbank, T. İş Bank, Garanti BBVA, Ziraat Bank, Yap1 Kredi Bank and Halkbank. 7 alternative banks were symbolized as A1, A2, A3, A4, A5, A6 and A7.

Criterion weights obtained by AHP Method: 'confidence' criterion (23.58\%) takes the first place. Then, "understandability" (12.42\%), "superiority" (10.32\%), "processing speed" (10.10\%), "informing" (9.51\%), "integrity" (9,50\%), "innovation" (8.97\%), "image" (8.48\%), "visuality" (7.12\%).

It is ranked as A4, A3, A7, A1, A4, A6, A2 by MOORA Ratio Method. According to the method, it is seen that $\mathrm{A} 3$ bank is more advantageous than other banks in terms of Digital Banking customer satisfaction. Ranking by MOORA Reference Point Method is A3, A7, A1, A4, A6, A5 and A2.

According to the ELECTRE Method, it is seenthat A1 bank is more advantageous than other banks in terms of Digital Banking customer satisfaction. Ranking by ELECTRE Method: A1, A7, A3, A4, A2, $\mathrm{A} 5$ and $\mathrm{A} 6$. As a result, it is seen that $\mathrm{A} 3$ and $\mathrm{A} 7 \mathrm{banks}$ have higher customer satisfaction.

The results of the studies in the literature (where 'trust' criteria has an important effect on customer satisfaction) are parallel with the results obtained from this study. Banks should pay attention to the 'trust' criterion to ensure the satisfaction of their customers using Digital Banking products.

In future studies, application can be carried out in other provinces. Mixed methods can be preferred and other MCDM Methods can be included in the studies, the results to be obtained can be compared with each other. Satisfaction with digital banking products and the 'trust' criterion, which has the highest rate among banks 'service quality' criteria, is the concern that customers' information will be captured and shared in other media. Banks should advise their customers on these issues, send confirmation and information messages to customers regarding every transaction, all banking transactions should be carried out based on the principle of transparency and measures should be taken against fraudulent transactions. The ways for banks to give confidence to their customers are to keep their service quality high, to ensure rapid transformation of products and services in line with the expectations of customers with increasing technological developments, and to have strong capital adequacy ratios of banks. The adequacy of the technological infrastructure of the banks in the increasing competition and technology environment is also important in terms of giving confidence to the bank customers. 